\title{
Study of the Anti-Inflammatory Activity of Flavonic Extract of Globularia alypum $\mathbf{L}$.
}

\author{
K. Boutemak ${ }^{a, *}$, B. SAFta ${ }^{b}$, N. AyACHI ${ }^{c}$ \\ ${ }^{a}$ Laboratoire d'Analyse Fonctionnelle des Procédés Chimiques, Université Blida 1, \\ rt. de Soumaa, Blida, 09000, Algérie \\ ${ }^{b}$ Département de Chimie, Faculté des Sciences, Université Blida 1, rt. de Soumaa, Blida, 09000, Algérie \\ ${ }^{c}$ Département de Pharmacie, Faculté de Médecine, Université Blida 1, rt. de Soumaa, Blida, 09000, Algérie \\ Globularia alypum $L$. of the family Globulariaceae is widely used in traditional medicine for its anti- \\ inflammatory activity. The aim of this study is to evaluate the anti-inflammatory activity of flavonic extract \\ (butanol fraction) of globularia alypum against carrageenan induced paw-oedema in mice. The results have shown \\ that the dose of $0.3 \mathrm{~g} / \mathrm{ml}$ of butanol fraction present the most significant activity $(33.01 \%)$ compared with reference \\ product aspirine $(39.76 \%)$ at dose of $2 \mathrm{mg} / \mathrm{ml}$
}

DOI: 10.12693/APhysPolA.128.B-239

PACS: $87.85 .-\mathrm{d}$

\section{Introduction}

Medicinal plants have been identified and used throughout human history. Thus, the medicinal plants' usage has gradually abandoned the empirical method and become based on explicatory facts [1]. According to data from the World Health Organization (WHO), more than $80 \%$ of the population of developing countries still relies on medicine originating from natural plants as their main source of healthcare [2]. Globularia alypum L. is an aromatic and medicinal plant belonging to the Globulariaceae family, found throughout the Mediterranean area and largely used and considered for its therapeutic virtues [3]. In Algeria, this specie known under the name "Tasselgha" is widely used in folk medicine for these many properties: anti-inflammatory drug, anti-ulcer, antidiabetic, antioxidant, cardiovascular, renal diseases and various cancer lesions of the stomach, colon, rectum and oesophagus [4]. It is distributed in the Saharan Atlas, Hoggar in altitude, in the forests of Algeria [5].

Inflammation is the body response to infection, tissue injury or invasion by microorganisms. It is considered a protective measure taken by the organism to remove the cause and promote the regeneration of the tissue that was injured [6]. The aim of the present study is evaluate the flavonic extract (butanol fraction) of Globularia alypum for anti-inflammatory activity.

\section{Materials and methods 2.1. Plant material}

The aerial part of Globularia alypum L. was collected in March 2013 from Hammam melouane a mountainous area, located approximately at $40 \mathrm{~km}$ in the south

\footnotetext{
*corresponding author; e-mail: kboutemak@yahoo.fr
}

of Algiers (North Algeria). Plant material was identificated and authenticated by the botanic laboratory of El Hamma (Algiers, Algeria) according to the Algerian flora and voucher specimen.

\subsection{Animals}

Fifty four adults albino mice of either sex weighing 19-21 $\mathrm{g}$ were housed in stainless steel cages at a temperature of $22 \pm 2{ }^{\circ} \mathrm{C}$ with a $12 \mathrm{~h}: 12 \mathrm{~h}$ dark:light cycle and relative humidity of $50 \%$. They were fed with standard diet and water ab libitum.

\subsection{Extraction and isolation}

$100 \mathrm{~g}$ of dried aerial part in shade at room temperature was powdered. The total hydroalcoholic extract was obtained by maceration with $50 \%$ ethanol. This procedure was repeated three times. After filtration, the residue was discarded and the solvent was evaporated to obtain the crude hydroalcoholic extract. A general procedure for extracting of flavonoid-rich fraction was based on liquidliquid extraction of total extract with $n$-butanol.

\subsection{Anti-inflammatory activity paw}

Flavonic extract (butanolic fraction) from globularia alypum was tested for anti-inflammatory activity against carrageenan induced paw-oedema in mouse (Levy test) [7]. Carrageenan induced paw oedema is the standard experimental model of acute inflammation. It is the phlogistic agent of choice for testing anti-inflammatory drugs. Acetylsalicylic acid was taken as a reference standard anti-inflammatory drug. Albino mice of either sex were divided into five groups of six animals. The dosage of the drugs administered to the different groups was as follows:

- Group I: witness control (normal saline $0.5 \mathrm{ml}$ ),

- Group II: Butanolic extract $(0.1 \mathrm{~g} / \mathrm{ml})$, 
- Group III: Butanolic extract $(0.2 \mathrm{~g} / \mathrm{ml})$,

- Group IV: Butanolic extract $(0.3 \mathrm{~g} / \mathrm{ml})$,

- Group V: positive control (acetylsalicylic acid, $2 \mathrm{mg} / \mathrm{ml})$.

The animals were pre-treated with normal saline (witness control), acetylsalicylic acid (reference standard used as positive control) and with Globularia alypum extracts, 30 min prior to the induction of the oedema. Thereafter, $0.025 \mathrm{ml}$ of $0.1 \% \mathrm{~W} / \mathrm{V}$ carrageenan solution was injected under the subplantar aponeurosis of the left hind paw of each mice and the right paw was served as the control. The paw volume was measured using plethysmometer. The activity of tissue measurement paw oedema (MPO) was assessed $4 \mathrm{~h}$ after injection of carrageenan. The percentage of inhibition in drugs treated mice versus control was calculated using the following formula:

inhibition paw oedema $=[(C-T) / C] \times 100 \%$.

$C$ - increase in paw-volume of control group; $T$ - increase after administration of extracts.

\section{Results and discussions}

Butanolic fraction of Globularia alypum was tested for anti-inflammatory activity against carrageenan induced paw oedema in mice. The percentage reduction in the paw volume in the group of animals treated with butanolic fraction at $0.1 \mathrm{~g} / \mathrm{ml}$ exhibits a lower effect $(8.55 \%)$ compared to the effect caused by acetylsalicylic acid (reference) $(39.76 \%)$ and for the $0.2 \mathrm{~g} / \mathrm{ml}$ was $27.15 \%$ at $4 \mathrm{~h}$. The anti-inflammatory activity of butanolic fraction is more significant marking a percentage of reduction of $33.01 \%$ for $0.3 \mathrm{~g} / \mathrm{ml}$.
TABLE

Inhibition paw oedema after $240 \mathrm{~min}$ [\%]

\begin{tabular}{c|c|c|c|c|c}
\hline \hline & \multirow{2}{*}{$\begin{array}{c}\text { normal } \\
\text { saline }\end{array}$} & $\begin{array}{c}\text { positive } \\
\text { control }\end{array}$ & \multicolumn{3}{|c}{ group } \\
\cline { 3 - 6 } & & II & III & IV \\
\hline $\begin{array}{c}\text { inhibition paw } \\
\text { oedema [\%] }\end{array}$ & - & $39.76 \%$ & $8.55 \%$ & $27.15 \%$ & $33.01 \%$
\end{tabular}

\section{Conclusion}

The evaluation of anti-inflammatory activity of flavonic extract of Globularia alypum has shown that for $0.3 \mathrm{~g} / \mathrm{ml}$, the percentage inhibition of paw oedema was $33.01 \%$ in comparing with acetylsalicylic $2 \mathrm{mg} / \mathrm{ml}$ where the percentage paw volume reduction is $39.76 \%$. Therefore, the extract has a significant effect on inflammation and reduced the swelling, having anti-inflammatory activity against the carragenan induce paw oedema in mice.

\section{References}

[1] B.B. Petrovska, Pharmacogn. Rev. 6, 1 (2012).

[2] J.B. Calixto. Braz. J. Med. Biol. Res. 33, 179 (2000).

[3] B. Fehri, J.M. Aiache, KK.M. Ahmed, Pharmacogn. Rev. 4, 138 (2012).

[4] A. Djeridane, M. Yousfi, B. Nadjemi, D. Boutassouna, P. Stocker, N. Vidal, J. Food Chem. 97, 654 (2006).

[5] A.D. Lucienne, Les plantes médicinales d'Algérie, Berti Édition, 2nd ed., 2010, p. 138.

[6] J.C. Castardo, A.S. Prudente, J. Ferreira, Cl.L. Guimaraes, F.D. Monached, V.C. Filho, M.F. Otuki, D.A. Cabrini, J. Ethnopharmacol. 118, 405 (2008).

[7] L. Levy, Life Sci. 8, 601 (1969). 